
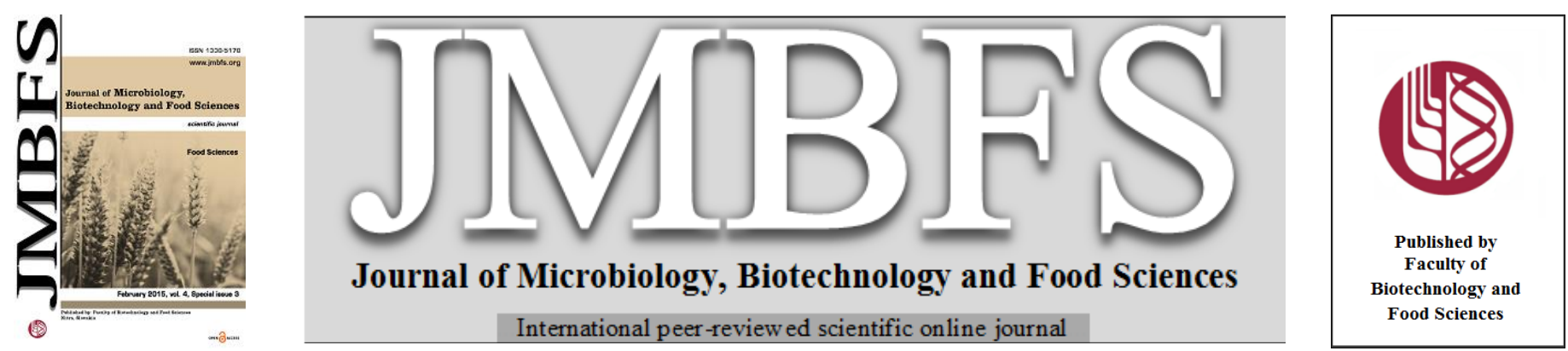

\title{
THE CONTENT OF Cd, Pb AND Hg IN THE GRAIN OF MAIZE (ZEA MAYS L.) HARVESTED IN THE ALLUVIAL SOILS OF THE UPPER REACHES OF THE RIVER NITRA
}

\section{Radovan Stanovič*, Michal Kujovský, Alena Vollmannová, Július Árvay, Janette Musilová}

Address(es): Ing. Radovan Stanovič, PhD.

Slovak University of Agriculture, Faculty of Biotechnology and Food Sciences, Department of Chemistry, Tr. A. Hlinku 2, 94976 Nitra, Slovakia, +421 376414248.

*Corresponding author: radovan.stanovic@gmail.com

doi: 10.15414/jmbfs.2015.4.special3.142-144

\section{ART ICLE INFO}

Received 27. 11.2014

Revised 3. 12. 2014

Accepted 4. 12. 2014

Published 2. 2. 2015

Regular article

open $\partial_{\text {ACCESS }}$

\begin{abstract}
The region of UpperNitra has been influenced for several decades by the intensive activity of the industry. The Nitra is a river with the most polluted water ecosystems. It was caused by anthropogenic activities in the past decades. In the upper reaches of the river in the cadastral territory of the village Zemianske Kostolany is located the thermal power plant. There is the sedimentation reservo ir, which caused the ecological disaster in 1965. During this accident there was a bursting of the dam and the downstream sedimentation of sludge spill, which cont aminated the entire water catchment area of the Nitra river. As a result of an ecological accident occurred to a long-term contamination of the stream but also the adjacent alluvial areas by heavy metals ( $\mathrm{Hg}, \mathrm{As}, \mathrm{Pb}$ and others). In the present work, we have focused on ascertaining the level of contamination the adjacent plot of land and seeds of corn in the cadastral territory of Male Kršteňany. We ascertained the excess of the limit values in the case of $\mathrm{Hg}$ on the south side of the agricultural land in Malé Kršteňany, which borders with the stream of the river. The $\mathrm{Cd}$ content has exceeded the limit value at the five sampling places, in the case of lead, content does not exceed the limit value. The average mercury concentration in the grain of maize was $0.095 \mathrm{mg}^{-\mathrm{kg}^{-1}}$, which exceeds the limit value by $90.5 \%$. The average cadmium content in maize grain reached the value of $0.06 \mathrm{mg} . \mathrm{kg}^{-1}$. This value does not exceed the limit value. Average lead accumulation in the grain of maize was $0.54 \mathrm{mg} \cdot \mathrm{kg}^{-1}$, which exceeds 2.7 times the limit value. The results of analyzes indicate an increased level of land contamination by mercury and cadmium, which was reflected in an increased level of contamination by monitored metals of crops.
\end{abstract}

Keywords: Heavy metals, alluvial soils, maize

\section{INTRODUCTION}

The environment creates natural conditions for the existence of living organisms The primary sources of pollution are natural and anthropogenic activities. The heavy metals are the important part of these emissions. The heavy metals are not subject to naturaldegradation process and become a permanent component of nature. (Cibulka et al., 1991).

The heavy metals in soils are often unavailable to plants. Due to the processes taking place in the soil, part of heavy metal passes into biologically available forms and is received by plants and results in the contamination of crop (Petrríková, 1990). Distribution of contaminants in the plant is given physiological nature of plants. Some plants tend to accumulate contaminants in certain organs. The distribution is dependent on the mobility of the contaminant in plant tissues and conditions of its growth (Ernst et al., 2004). The acceptability metal by plants depends on many factors e.g. chemical form in which it is bound metal, it s solubility e.t.c. The important factors is soil pH. Most metals in a neutral to alkaline medium is not available to plants. In the slightly acidic and acid soils, at soil $\mathrm{pH}$ values $>5$, the metals come into acceptable form for plants (Baker, 1981).

Cadmium is a nonessential element for plants. It received mostly rooted plants, but there are also foliar cadmium directly from the atmosphere through cont aminated leaf surface (Hovmand, 1983). Cadmium intake by plant roots is a linear dependence on the concentration of free $\mathrm{Cd}^{2+}$ ions in the soil solution (Domažlická et al., 1989). The mobility of cadmium to the roots takes place by diffusion and mass flow of soil. In theimmediate vicinity of the roots occurs to the metal chelation with organic acids secreted plant, increases the diffusion gradient and speeds receiving metal (Mullins et al., 1986). Cadmium has similar geochemical and environmental characteristics such as zinc, said association of $\mathrm{Cd}$ and $\mathrm{Zn}$ in the environment and their chemical similarity can lead to mutual interactions while receiving plants, transport from the roots to the aerial parts of plants or accumulation in the edible parts and the Cd may enter into the food chain (Merian, 1991). In some cases, $\mathrm{Zn}$ suppresses bioaccumulation of $\mathrm{Cd}$ a reduction in its income, whereas in other cases supports $\mathrm{Zn}$ increase $\mathrm{Cd}$ bioaccumulation its income. Accumulation of $\mathrm{Cd}$ and $\mathrm{Zn}$ in plants and subsequent phytotoxicity depends on the plant species and varieties (He $\boldsymbol{e t}$ al. 2004). It is generally believed that the interaction of $\mathrm{Cd}-\mathrm{Zn}$ is based on phenomenon competitive inhibition, where cadmium and zinc compete for a similar active centers vector (Cibulka, 1986).

Lead is one of the least mobile elements of heavy metals. Naturally tends to accumulate in the surface soil horizons, primarily in connection with an increased incidence of organic matter, partly due to atmospheric pollution (Tessier et al. 1979). It binds to humic acids and fulvic acids by bacterial action and subject to the alkylation (Rapant et al., 1996). Lead is a widespread soil contaminants. Its solubility and mobility are not low. Yet many environmental concentration values are high enough to raise the potential risk to health, particularly near large plants using $\mathrm{Pb}$ and in large cities. Lead can affect microbiological activity in soil, and thus cause a decrease in soil productivity (Alloway, 1990). Lead occurs naturally in all plants as well as in soil, air and water. Availability lead to terrestrial plants is limited because it tends to produce highly insoluble salts and complexes with various anions. Translocation of the lead ion is limited and most of lead remain on the roots or on the leaf surface. (Mitchell, 1963).

Concentrations of mercury worldwide in surface soils are in the range of $0.003-$ 4.6 $\mu \mathrm{g}^{-\mathrm{g}^{-1}}$ (Steinnes, 1997). Locally the mercury concentration can be several times higher (e.g. up to $557 \mathrm{mg} \cdot \mathrm{kg}^{-1}$ near the electrolytic production equipment hydroxides in Ganju in India (Lenka $\boldsymbol{e t}$ al., 1992). We can currently source contamination of the environment with mercury divided into the primary source, of which is not directly related to human activity and secondary source, which is directly or indirectly theresult of human activity (Závadská et al., 1999). Many studies have shown that plant roots accumulate $\mathrm{Hg}$ from contaminated soils (Bersenyi et al., 1999; Kalac et al., 2000). Mercury is present in contaminated soil can affect all physiological and biochemical processes in plants (Patra et al., 2000). Hg cations have a high affinity for sulfhydryl groups (-SH). Because almost all proteins contain sulfhydryl groups or disulfide bridges (-SS-), Hg cation can disrupt almost all plant functions associated with proteins (Clarkson, 1972). 


\section{MATERIAL AND METHODS}

The reference locality that was chosen borders with river Nitra the agricultural area Malé Kršteňany. At the whole area we have chose 17 sampling sites in which $\mathrm{Cd}, \mathrm{Pb}$ and $\mathrm{Hg}$ contents were determined. The samples of alluvial soil from these places were taken by pedological probe GeoSampler (Fisher, USA). Pseudototal content of $\mathrm{Cd}$ and $\mathrm{Pb}$ including all of the forms besides residual fraction of metals was assessed in solution of aqua regia. From the same places were taken samples of maize grains. The contents of monitored contaminants were set in plant material and in the soil samples after mineralization in the environment of concentrated nitric acid of microwave assisted decomposition. The flame atomic absorption spectrometry (Varian 240 FS/240Z, USA) was the used as the analytical method for heavy metal levels det ermination. The obtained results were evaluated according to Law 220/2004 of the Slovak Republic.

\section{RESULTS AND DISCUSSION}

Based on measured values of $\mathrm{pH} / \mathrm{KCl}$ in soil of locality Malé Kršteňany we can confirm the neutral till alkali exchangeable soil reaction (the determined values of $\mathrm{pH} / \mathrm{KCl}$ ranged in interval $6.99-7.46$ ). The content of humus ranged in interval $1.09 \%-2.84 \%$, e.g. the supply of humus was low till medium. The average value of humus content was $1.85 \%$

In locality Malé Kršteňany the soil content of Cd was higher than limit value only in 5 sampling sites unlike river bank sediments, where determined values of $\mathrm{Cd}$ content exceeded the limit value in all sampling sites. The interval of enhanced values was $0.72 \mathrm{mg.kg}{ }^{-1}$ (sampling site no. 8) - $0.95 \mathrm{mg.kg}^{-1}$ (sampling site no. $10)$, which represents $2.9-35.7 \%$ exceeded limit value $\left(0.70 \mathrm{mg}^{-\mathrm{kg}^{-1}}\right)$. The average value of Cd concentration in all sampling sites was $0.56 \mathrm{mg} . \mathrm{kg}^{-1}$.

The $\mathrm{Pb}$ content determined in soils was below the limit value $70 \mathrm{mg} \cdot \mathrm{kg}^{-1}$ given by the legislation in all sampling sites. The highest determined $\mathrm{Pb}$ content was only $36.0 \mathrm{mg} \cdot \mathrm{kg}^{-1}$.

The determined $\mathrm{Hg}$ content exceeded the limit value in samples taken from 3 sampling sites $(13,16$ and 17) of the observed locality. The lowest determined value of $\mathrm{Hg}$ content $1.093 \mathrm{mg} . \mathrm{kg}^{-1}$ exceeded by $118.6 \%$ the limit value given by the legislation $\left(0.5 \mathrm{mg} \cdot \mathrm{kg}^{-1}\right)$ in sampling site no. 16 . The highest $\mathrm{Hg}$ content $(1.60$ $\mathrm{mg.k \textrm {g } ^ { - 1 }}$ ) was determined in smapling site no. 17. And exceeded the limit value by $220 \%$. The average $\mathrm{Hg}$ concetration in all observed sampling sites was 0.33 $\mathrm{mg} . \mathrm{kg}^{-1}$. The average $\mathrm{Hg}$ concetration in all observed sampling sites was 2.92 $\mathrm{mg} \cdot \mathrm{kg}^{-1}$ and exceeded the limit value by $484 \%$. All monit ored values from soil are in table. 1.

Table 1. Soil reaction, humus and heavy metals content in soil extract by aqua regia $\left(\mathrm{mg} \mathrm{kg}^{-1}\right)$ in the alluvial soils Malé Kršteňany

\begin{tabular}{|c|c|c|c|c|c|}
\hline \multirow{2}{*}{ No. } & \multirow{2}{*}{$\begin{array}{c}\text { pH } \\
(\mathrm{KCl})\end{array}$} & \multicolumn{2}{|c|}{$\begin{array}{c}\text { Aqua regia } \\
\left(\mathrm{mg}^{\prime} \mathrm{kg}^{-1}\right)\end{array}$} & \multirow{2}{*}{$\begin{array}{c}\begin{array}{c}\mathrm{AMA} \\
\left(\mathrm{mg}^{-\mathrm{kg}^{-1}}\right)\end{array} \\
\mathrm{Hg}\end{array}$} & \multirow{2}{*}{$\begin{array}{c}\text { Humus } \\
(\%)\end{array}$} \\
\hline & & Cd & $\mathbf{P b}$ & & \\
\hline 1. & 7.23 & 0.33 & 35.9 & 0.060 & 1.51 \\
\hline 2. & 7.35 & 0.74 & 31.1 & 0.067 & 1.75 \\
\hline 3. & 7.30 & 0.73 & 32.8 & 0.060 & 1.88 \\
\hline 4. & 7.36 & 0.52 & 36.0 & 0.056 & 1.09 \\
\hline 5. & 7.46 & 0.56 & 34.3 & 0.099 & 1.82 \\
\hline 6. & 7.40 & 0.53 & 30.2 & 0.082 & 1.69 \\
\hline 7. & 7.19 & 0.92 & 26.0 & 0.110 & 2.12 \\
\hline 8. & 7.38 & 0.72 & 29.6 & 0.109 & 1.75 \\
\hline 9. & 7.36 & 0.63 & 30.4 & 0.102 & 2.00 \\
\hline 10. & 7.20 & 0.95 & 30.5 & 0.102 & 2.12 \\
\hline 11. & 7.26 & 0.25 & 20.5 & 0.399 & 1.94 \\
\hline 12. & 7.36 & 0.42 & 24.7 & 0.222 & 2.00 \\
\hline 13. & 7.41 & 0.42 & 21.3 & 1.283 & 1.94 \\
\hline 14. & 7.35 & 0.56 & 21.7 & 0.097 & 1.69 \\
\hline 15. & 7.30 & 0.38 & 20.4 & 0.097 & 1.39 \\
\hline 16. & 7.19 & 0.41 & 22.0 & 1.093 & 1.88 \\
\hline 17. & 6.99 & 0.40 & 22.7 & 1.600 & 2.84 \\
\hline Limit value * & - & 0.7 & 70 & 0,5 & - \\
\hline Average & 7.30 & 0.56 & 27.65 & 0.332 & 1.85 \\
\hline Min. & 6.99 & 0.25 & 20.40 & 0.056 & 1.09 \\
\hline Max. & 7.46 & 0.95 & 36.00 & 1.600 & 2.84 \\
\hline St. dev. & 0.11 & 0.20 & 5.55 & 0.490 & 0.37 \\
\hline Median & 7.35 & 0.53 & 29.60 & 0.102 & 1.88 \\
\hline
\end{tabular}

Compared with the soil, where the limit value Cd exceeded only at five sampling sites, the content of $\mathrm{Cd}$ in the grain of maize was higher than the limit value in all samples, except for two that contained $0.01 \mathrm{mg}^{\mathrm{kg}}{ }^{-1}$, which is the exact limit value. The lowest concentration of Cd exceeded $\left(0.02 \mathrm{mg} \cdot \mathrm{kg}^{-1}\right)$ was in the sample 11 , the highest exceeded $\mathrm{Cd}$ concentration the value $\left(0,15 \mathrm{mg} \cdot \mathrm{kg}^{-1}\right)$ was in samples 15 and 16 , which represents 100 to $1400 \%$ of the exceeding of the limit value $\left(0.01 \mathrm{mg} \cdot \mathrm{kg}^{-1}\right)$. The average value of the concentration of cadmium from all points of supply is $0.06 \mathrm{mg} \cdot \mathrm{kg}^{-1}$.

Consequently, we focused on the lead content. In contrast to soil, where all sampling sites were not exceeded limits on concentrations of lead, in samples of grain corn was up 13 values above the limit concentration of $0.20 \mathrm{mg} \cdot \mathrm{kg}^{-1}$. The lowest exceeded concentration of $\mathrm{Pb}\left(0.3 \mathrm{mg} \cdot \mathrm{kg}^{-1}\right)$ was in the sample 9 , exceeded the maximum concentration value $\mathrm{Pb}\left(1.0 \mathrm{mg} \cdot \mathrm{kg}^{-1}\right)$ was in the sample 8 , representing 50 to $400 \%$ matching exceeding the limit value $\left(0.20 \mathrm{mg} \cdot \mathrm{kg}^{-1}\right)$. The average value of lead concentrations from all sampling sites is $0.54 \mathrm{mg} \cdot \mathrm{kg}^{-1}$. Finally, we measured the risk element that it concentration exceeded the limit value in all samples of grain corn was mercury. The lowest concentration of $\mathrm{Hg}$ $\left(0.0678 \mathrm{mg} \cdot \mathrm{kg}^{-1}\right)$, which exceeded the limit value $\left(0.05 \mathrm{mg} \cdot \mathrm{kg}^{-1}\right)$ was at the sampling point number 12 , which represents $35.6 \%$ of the exceeding of the limit value. The highest $\mathrm{Hg}$ concentration value $\left(0.1256 \mathrm{mg}^{\mathrm{kg}} \mathrm{kg}^{-1}\right)$ was at the sampling point number 15 . This concentration exceeds the limit value of $151.2 \%$. The average value of the mercury concentration at all sampling sites is $0.0952 \mathrm{mg} . \mathrm{kg}$ 1 . All monitored values from corn seed soil are in table. 2 . 
Table 2. Heavy metals content in corn seed $\left(\mathrm{mg}^{\mathrm{kg}} \mathrm{kg}^{-1}\right)$ from Malé Kršteňany

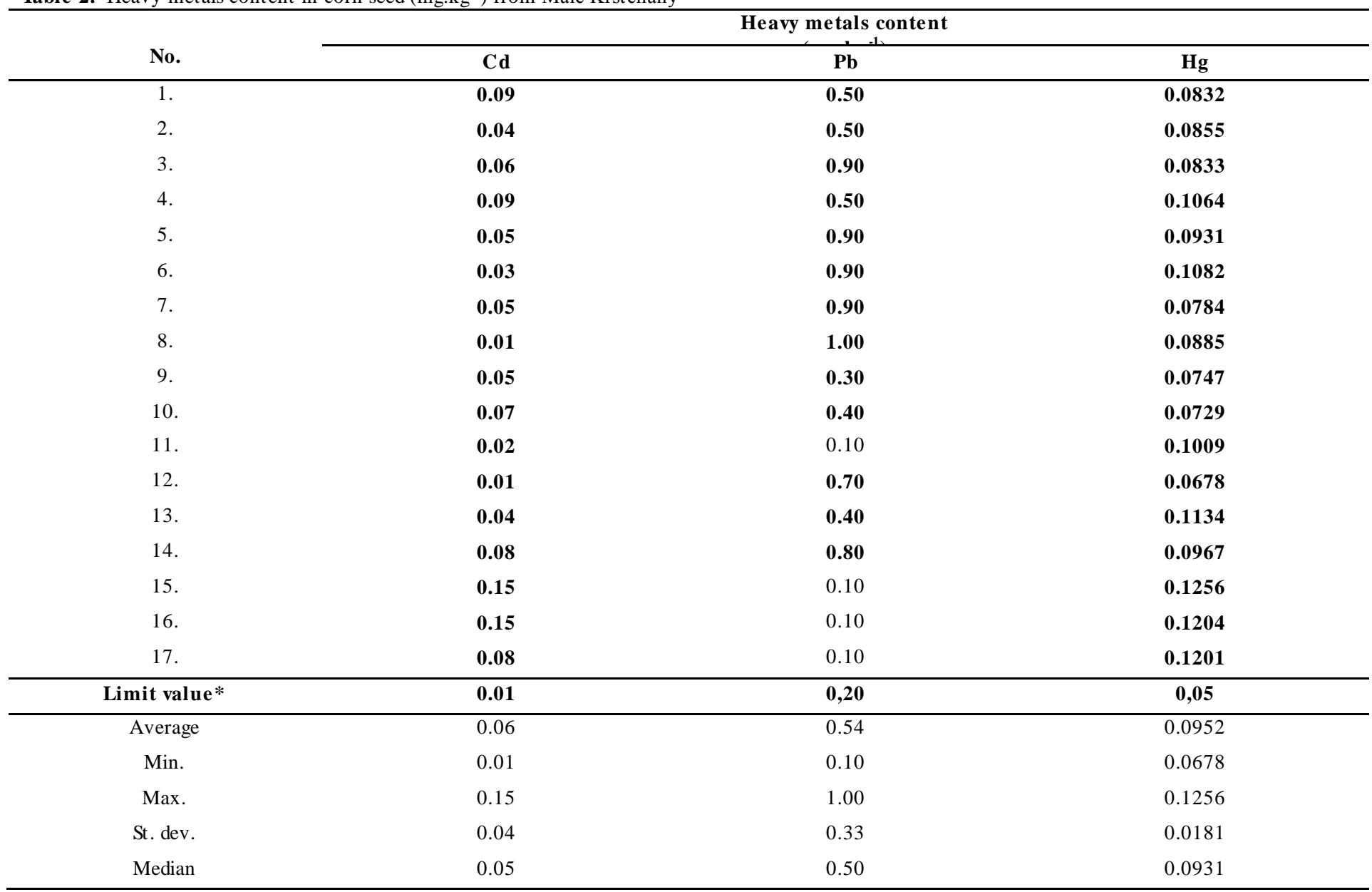

\section{CONCLUSION}

The study was focused on the contamination level of alluvial soil in Malé Kršteňany cadaster bordered, with river Nitra and agricultural crops of maize grown on this parcel. The observed locality was hit by torrential wave due by breakage of the dam in power plant Zemianske Kostol'any. In this accident an unspecified amount of sludge sedimentation has leaked, which significantly contaminated alluvial area of the river Nitra. The obtained results confirm the high level of contamination of corn seed by cadmium, lead and mercury. The exceeding of the limit value was even up to $1400 \%$ for Cd, even up to $400 \%$ for $\mathrm{Pb}$ and more than $151 \%$ for $\mathrm{Hg}$. Results of monitored heavy metal contents in agricultural soil of chosen locality Malé Kršteňany were more favorable in comparison with corn seed, but the high risk of mercury transport from soil into agricultural production was recorded on the southeast side of the locality bordering the river flow. The results confirm that, even at present, negative consequences of old environmental burdens on the aquatic ecosystem of the river Nitra as well as on agricultural production concentrated near the river are evident. The agricultural raw materials are exposed to potential risks of transfer of investigated contaminants in soil-plant system.

Acknowledgments: This work was supported by the project VEGA 1/0456/12.

\section{REFERENCES}

ALLOWAY, B. J. 1990. Heavy Metal in Soils. Halsted Press, Wiley, London. BAKER, A. J. M. 1981. Accumulators and excluders-strategies in the response of plant to heavy metals. Journal of Plant Nutrition, 3, 643p.

BERSENYI, A., FEKETE, S., HULlAR, I., KADAR, I., SZILAGYI, M., GLAVITS, R., KULCSAR, M., MEZES, M., ZOLDAG, L. 1999. Study of the soil-plant (carrot)-animal cycle of nutritive and hazardous minerals in a rabbit model. Acta Veterinaria Hungarica, 47, p. 181-190.

CIBULKA, J. 1986. Pohyb olova, kadmia a rtuti v zemědělské výrobě a biosféře. Praha : SZN, $157 \mathrm{p}$.

CIBULKA, J., DOMAŽLICKÁ,E., KOZÁK, J. 1991. Pohyb olova, kadmia a rtuti v biosféře. Praha: Academia, 432 p. ISBN 80-200-0401-7

CLARKSON, T. W. 1972. The pharmacology of mercury compounds. Annual Review of Pharmacology and Toxicology, 12, p. 375-406.

DOMAŽLICKÁ,E., OPATRNÝ,Z. 1989. The effects of cadmium on potato (Solanum tuberosum L.) shoot culture growth. Biology Plantarum, 31, 5, p. 408412 .
ERNST, W. H. O., KNOLLE, F., KRATZ, S., SCHNUG, E. 2004. Aspects of ecotoxicology of heavy metals in the Harz region - a quided excursion. Landbauforschung Völkenrode, vol. 54, $53-71$.

HE, P. P., LU, X. Z., WANG, G. Y. 2004. Effects of Se and Zn supplementation on the antagonism against $\mathrm{Pb}$ and $\mathrm{Cd}$ in vegetables. In Environment International, 30, p. 167-172.

HOVMAND, M. F. 1983. Plant uptake of airborn cadmium. Environmental Pollution. 30, 3, p. 27-38.

KALAC, P., SVOBODA, L. 2000. A review of trace element concentrations in edible mushrooms. Food Chemistry, 69, p. 273-281.

LENKA, M., PANDA, K. K., PANDA, B. B. 1992. Monitoring and assessment of mercury pollution in the vicinity of a chloralkali plant. 4 . Bioconcentration of mercury in in-situ aquatic and terrestrial plants at Ganjam, India. Archives $O f$ Environmental Contamination And Toxicology, 22, p. 195-202.

MERIAN, E. 1991. Metals and Their Compounds in the Environment. Verlagsgesellschaft VCH, Weinheim.

MITCHELL, R. L. 1963. Soil aspects of trace element problems in plants and animals. Journal of the Royal Agricultural Society of England, 124, p. 75-86. MULLINS, G. L, SOMMERS, L. E. 1986. Characterization of Cadmium and Zinc in Four Soils Treated with Sewage Sludge. Journal of Environmental Quality, 15, p. 382-387.

PATRA, M., SHARMA, A. 2000. Mercury toxicity in plants. The Botanical Review, 66, p. 379-421.

PETŘÍKOVÁ, V. 1990. Výskyt imisí v ovzduší a obsah těžkých kovů v zemědělských plodinách. Rostlinná výroba, vol. 36, 367-377.

RAPANT, S., VRANA, K., BODIŠ, D. 1996. Geochemický atlas Slovenska. Čast' 1 - Podzemné vody. Bratislava : GS SR, Vyd. D. Stúra, 127 p.

STEINNES, E. 1997. Mercury. ALLOWAY, B. J. (Ed.) Heavy Metals In Soils (Second Edition). Blackie Academic Professional Press, London, UK. p. 245259.

TESSIER, A., CAMPBELL, G. C., BISSON, M. 1979. Sequential extraction procedure for speciation of particulate trace metals. Analytical Chemistry, 51, p. 844-851.

ZÁVADSKÁ, M., ŽEMBERYOVÁ, M. 1999. Stanovenie a špeciácia zlúčenín ortuti vo vzorkách životného prostredia technikami metódy AAS. Chemické Listy, 93, p. 91-98. 